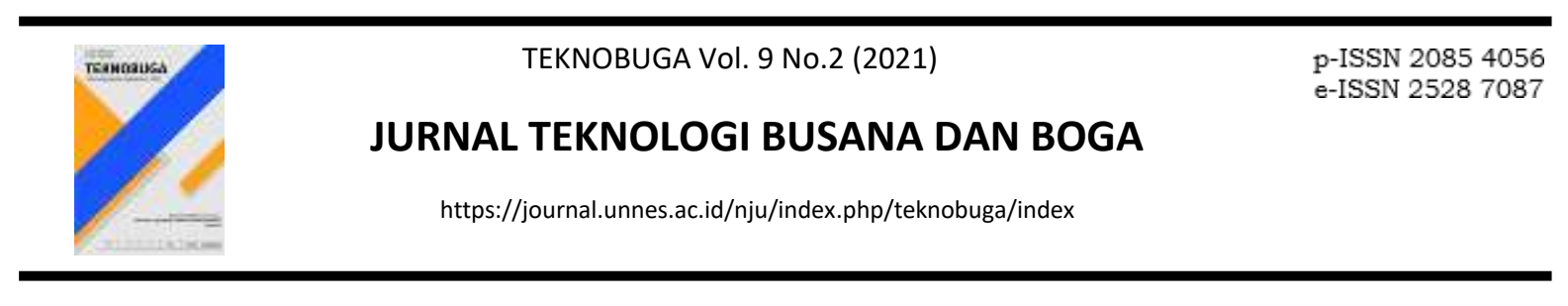

\title{
EFEKTIVITAS PELATIHAN HAZARD AND SAFETY UNTUK MENINGKATKAN KOMPETENSI MAHASISWA DALAM MELAKSANAKAN UNIT PRODUKSI SALON KECANTIKAN DI ERA NEW NORMAL
}

\author{
Sofia Daniati ${ }^{1, a)}$, Nurulisma Saputri ${ }^{1)}$ \\ ${ }^{1}$ Program Studi Tata Rias, AKS Ibu Kartini Semarang. \\ a) Corresponding author: sofia@aksibukartini.ac.id
}

\begin{abstract}
The production unit has a very important role as a place for entrepreneurship training for students. However, with the covid pandemic, all learning activities are carried out online and the production unit activities automatically stop because there are no rules for implementing the production unit according to the health protocol. Therefore, there is a need for hazard and safety training for beauty salons in the new normal era before students manage production units with the aim of improving students' attitudes and level of understanding in managing production units in accordance with health protocols. This type of research is a type of pre-experimental research design with one group pre-test and post-test design. The data collection method used is the test. In this study, there were two treatments using an instrument in the form of a test. The test in question is the Pre-Test, which is a test carried out before the training and Post-Test, which is a test carried out after the training. The difference in the mean scores of students' attitudes and understanding before and after the training was calculated using the Paired T-Test. The results of the study on the knowledge assessment indicators showed a significance result of $<0.05$, so it can be said that there is a significant difference between the knowledge shown by students before and after hazard and safety training. In the attitude assessment indicator, the significance value $<0.05$, the paired sample $t$ test results show that hazard and safety training can improve student attitudes in carrying out production units in the new normal era according to health protocols.
\end{abstract}

Keywords: Training Unit Production, New Normal.

Abstrak. Unit produksi memiliki peranan yang sangat penting sebagai tempat pelatihan berwirausaha bagi peserta didik. Namun, dengan adanya pandemic covid mengharuskan seluruh kegiatan pembelajaran dilakukan secara daring dan otomatis kegiatan unit produksi terhenti karena belum adanya aturan pelaksanaan unit produksi sesuai protokol kesehatan. Oleh karena itu perlu adanya pelatihan hazard and safety salon kecantikan di era new normal sebelum mahasiswa mengelola unit produksi dengan tujuan untuk meningkatkan sikap dan dan tingkat pemahaman mahasiswa dalam pengelolaan unit produksi sesuai dengan protocol kesehatan. Jenis penelitian ini merupakan jenis penelitian preexperimental designs dengan rancangan penelitian one group pre test dan post test design. Metode pengumpulan data yang digunakan yaitu tes. Dalam penelitian ini terdapat dua perlakuan dengan menggunakan instrumen berupa tes. Tes yang dimaksud adalah Pre-Test yaitu tes yang dilaksanakan sebelum adanya pelatihan dan Post-Test yaitu tes yang dilaksanakan sesudah pelatihan. Perbedaan rerata skor sikap dan pemahaman mahasiswa sebelum dan sesudah pelatihan dihitung menggunakan Uji Paired T-Test. Hasil penelitian pada indikator penilaian pengetahuan menunjukan hasil signifikansi $<0,05$ maka dapat dikatakan bahwa terdapat perbedaan yang nyata antara pengetahuan yang ditunjukan mahasiswa sebelum dan sesudah pelatihan hazard and safety. Pada indikator penilaian sikap hasil siginifikasi < 0,05 maka hasil uji paired sample t test menunjukan bahwa pelatihan hazard and safety dapat meningkatkan sikap mahasiswa dalam melaksanakan unit produksi di era new normal sesuai protokol kesehatan. Berdasarkan hasil penelitian, dapat disimpulan bahwa mahasiswa yang memiliki tingkat pemahaman tentang konsep hazard and safety yang baik, akan mendorong sikap positif.

Kata Kunci: Pelatihan Unit Produksi, New Normal. 


\section{PENDAHULUAN}

Merebaknya virus korona di tanah air menambah tantangan sekaligus kekhawatiran bagi pelaku usaha ataupun kalangan pekerja dan berdampak pada berbagai bidang salah satunya pada bidang pendidikan. Sesuai surat Edaran Nomor 4 Tahun 2020 tentang Pelaksanaan Pendidikan Dalam Masa Darurat Coronavirus Disease (Covid-19) mengharuskan segala kegiatan belajar mengajar dilakukan secara daring dirumah. Perguruan tinggi dituntut untuk dapat menyelenggarakan pembelajaran secara daring atau online (Firman, F., \& Rahayu, S., 2020). Menurut Moore, Dickson-Deane, \& Galyen (2011) Pembelajaran daring merupakan pembelajaran yang menggunakan jaringan internet dengan aksesibilitas, konektivitas, fleksibilitas, dan kemampuan untuk memunculkan berbagai jenis interaksi pembelajaran. Penelitian yang dikakukan oleh Zhang et al., (2004) menunjukkan bahwa penggunaan internet dan teknologi multimedia mampu merombak cara penyampaian pengetahuan dan dapat menjadi alternatif pembelajaran yang dilaksanakan dalam kelas tradisional. Pembelajaran daring adalah pembelajaran yang mampu mempertemukan mahasiswa dan dosen untuk melaksanakan interaksi pembelajaran dengan bantuan internet (Kuntarto, E. (2017).

Pandemi COVID-19 yang tengah mengubah tatanan kehidupan sosial masyarakat menjadi faktor eksternal yang memengaruhi proses pembelajaran saat ini (Strielkowski, 2020). Dengan berlakunya protokol kesehatan di masa pandemi, kegiatan kegiatan pembelajaran dalam bentuk praktik di bengkel kerja otomatis tidak dapat dilakukan sebagaimana mestinya. Jamaluddin, D., Ratnasih, T., Gunawan, H., \& Paujiah, E. (2020) menyatakan bahwa pembelajaran daring memiliki kekuatan, tantangan dan hambatan tersendiri. Terlebih ketika pembelajaran yang dilaksanakan adalah praktik. Pembelajaran praktik ini tidak dapat dihilangkan begitu saja. Pembelajaran praktik pada pendidikan vokasi dilakukan melalui daring, memberikan kesenjangan yang cukup besar dengan aktivitas pembelajaran yang seharusnya dilakukan mahasiswa. Pembatasan aktivitas di ruang publik dalam skala besar tidak memungkinkan mahasiswa untuk datang dan melakukan praktik di lingkungan kampus. Di sisi lain, hilangnya kegiatan praktik di bengkel kerja seperti seharusnya ini memberikan dampak signifikan pada menurunnya pengalaman mahasiswa dalam melakukan praktik dengan berbagai peralatan praktik yang tersedia di bengkel kerja. Keadaan ini memberi dampak pada kegiatan unit produksi sebagai tempat berwirarausaha mahasiswa banyak mengalami kendala dalam pelaskanaannya. Unit produksi merupakan sarana praktek langsung bagi peserta didik dalam menerapkan kemampuan dan ketrampilan yang dimiliki, sehingga peserta didik dapat mengembangkan potensi sebagai calon usahawan atau tenaga kerja sesuai kemampuannya. Menurut Mahfud dan Pardjono (2012: 29) hadirnya unit produksi dapat memberikan pengalaman kerja nyata (real to work) bagi siswanya agar menguasai kompetensi produktif secara profesional. Di samping itu, peserta didik juga dipersiapkan untuk menjadi pribadi-pribadi wirausahawan agar tamatannya tidak hanya menjadi pencari kerja (job seeker) tetapi juga dapat menjadi pencipta lapangan kerja (job creator). Unit produksi yang akan menjadi fokus utama penelitian adalah unit produksi yang bergerak pada bidang salon kecantikan di AKS Ibu Kartini Semarang, yang mana bidang usaha salon kecantikan, spa dan sanggar rias sangat merasakan dampak dari adanya pandemic ini. Pasalnya, pada kegiatan unit produksi yang bergerak pada bidang salon dan sanggar rias baik pelanggan maupun beautician diharuskan berada dalam jarak dekat. Hal ini tidak mungkin dilakukan karena dapat membawa risiko sehingga selama masa pandemic ini kegiatan unit produksi terpaksa dihentikan.

Pentingnya kegiatan unit produksi sebagai sarana pelatihan wirausaha bagi mahasiswa dalam menerapkan kemampuan dan ketrampilan di bidang wirausaha inilah diperlukan suatu strategi pelaksanaan unit produksi agar unit produksi tetap dapat dilaksanakan sesuai dengan protokol kesehatan di tengah masa pandemic covid19 sesuai dengan Surat Kementerian Kesehatan Nomor HK.01.07/MENKES/382/2020 tentang Protokol Kesehatan Bagi Masyarakat Di Tempat Dan Fasilitas Umum. Menurut Bayu Anggara Silvatika (30:2020) Implementasi regulasi tersebut menjadikan suatu kehidupan normal baru (new normal), dimana seluruh aktivitas masyarakat diwajibkan mengikuti protokol kesehatan, termasuk juga dalam kegiatan usaha. New normal mendorong mahasiswa untuk melakukan shifting baik perilaku maupun aktivitas dalam mengelola unit produksi. Perubahan-perubahan tersebut merupakan keniscayaan agar unit produksi tetap efektif dalam pemanfaatannya sebagai tempat pelatihan berwirausaha. Perubahan aktivitas yang sebelumnya mengabaikan kesehatan, sekarang menjadi mengutamakan protokol kesehatan dan memperhatikan aspek sosial. Selain itu, kondisi new normal ini juga mendorong evolusi usaha yang sebelumnya offline, sekarang menjadi online. Oleh karena itu, diperlukan suau pelatihan tentang hazard and safety unit produksi di era new normal sebagai persiapan dalam melaksanakan pembelajaran di unit produksi. Pelatihan hazzard and safety merupakan salah satu upaya bagi mahasiswa dalam menerapkan protokol kesehatan ketika melaksanakan kegiatan praktik di unit produksi . Mahasiswa perlu mengetahui konsep hazard and safety sebagai rencana kesiapsiagaan yang komprehensif untuk mengatasi krisis kesehatan yang sedang terjadi, sehingga mahasiswa dan unit produksi sebagai tempat pelatihan berwirausaha dapat lebih siap menghadapi era new normal. Pelatihan tersebut diadakan dengan tujuan agar pembelajaran pada unit produksi jasa salon kecantikan di AKS Ibu Kartini Semarang tetap bisa berjalan, walaupun di tengah pandemic Covid-19.

Beberapa faktor yang memungkinkan dapat mempengaruhi pelaksanaan unit produksi di era new normal 
adalah faktor sikap mahasiswa dan pemahaman mahasiswa tentang materi hazard and safety. Menurut Suharto et al.(2020) Sikap dapat menjadi suatu predisposisi untuk bersikap dan bertindak. Faktor penyebab terjadinya perilaku pada diri seseorang merupakan pengetahuan dan sikap seseorang terhadap apa yang telah dilakukan, Perubahan pengetahuan dan sikap individu dimulai dengan tahap kepatuhan, melakukan identifikasi kemudian menjadi internalisasi. Jika mahasisa diberikan stimulus positif berulang-ulang tentang pentingnya memperhatikan bahaya dan keamanan dalam melakukan kegiatan praktek baik di bengkel kerja ataupun di unit produksi, mahasiswa akan merespon dengan sikap yang positif untuk dapat lebih berhati-hati dalam melaksanakan kegiatan perkuliahan dengan mematuhi protokol kesehatan. Sedangkan penguasaan materi tentang hazard and safety merupakan seberapa besar pengetahuan dan pemahaman siswa tentang hazard and safety. Pengetahuan dapat diperoleh dari pendidikan formal maupun pendidikan informal. Makin tinggi tingkat pendidikan formal seseorang, maka semakin luas pengetahuannya. Pemberian pelatihan merupakan salah satu langkah untuk meningkatkan pemahaman mahasiswa dan sikap mahasiswa dalam melaksanan kegiatan di unit produksi salon kecantika di era new normal, hal ini sesuai dengan pendapat Peng, et al (2020) bahwa pengetahuan akan meningkat, dan mendorong sikap positif

\section{METODE}

Berdasarkan judul penelitian yaitu efektivitas pelatihan hazard and safety untuk meningkatkan kompetensi mahasiswa dalam melaksanakan unit produksi salon kecantikan di era new normal, maka penelitian ini merupakan penelitian eksperimen. Tujuan pelatihan ini diselenggarakan pada program studi tata rias AKS Ibu Kartini Semarang adalah sebagai upaya dalam memaksimalkan kegiatan pada unit produksi sehingga mahasiswa tetap mendapatkan sarana pelatihan dalam mengembangakan ketrampilan dan kemampuan sebagai bekal terjun di dunia kerja sebagai tenaga kerja ataupun wirausaha. Jenis penelitian ini merupakan jenis penelitian preexperimental designs dengan rancangan penelitian one group pre test dan post test design. Variabel bebas ini adalah pelatihan hazard and safety dan variabel terikatnya adalah kompetensi mahasiswa berupa sikap dan tingkat pemahaman tentang konsep hazard and safety salon kecantikan dalam melaksanakan unit produksi di masa pandemic covid19.

Subyek penelitian dalam penelitian ini adalah mahasiswa semester 4 dan semester 6 yang terlibat dalam kegiatan UP yang berjumlah 60 orang dengan teknik penentuan sampel menggunakan teknik sensus sampling yaitu semua anggota populasi digunakan menjadi sampel. Metode pengumpulan data yang digunakan yaitu tes. Dalam penelitian ini terdapat dua perlakuan dengan menggunakan instrumen berupa tes. Tes yang dimaksud adalah Pre-Test yaitu tes yang dilaksanakan sebelum adanya pelatihan dan Post-Test yaitu tes yang dilaksanakan sesudah pelatihan. Perbedaan rerata skor sikap dan pemahaman mahasiswa sebelum dan sesudah pelatihan dihitung menggunakan Uji Paired T-Test.

\section{HASIL DAN PEMBAHASAN}

Pelatihan hazzard and safety pelaksanaan unit produksi di era new normal perlu diselenggarakan sebelum mahasiswa mengelola unit produksi dengan tujuan untuk meningkatkan sikap dan dan tingkat pemahaman mahasiswa dalam pengelolaan unit produksi sesuai dengan protokol kesehatan..

Berdasarkan perhitungan hasil tes yang telah dilakukan kepada mahasiswa, pelatihan yang diselenggaran dianggap efektif apabila hasil Posttest $>$ dari Pretest. Pada tabel 1 menyajikan hasil penilaian tingkat signifikansi pelatihan hazard and safety pada aspek kognitif mahasiswa sebelum dan sesudah pelatihan dapat dilihat pada tabel berikut:

Tabel 1. Aspek Pengetahuan

\begin{tabular}{lllll}
\hline Aspek & Indikator & sig & A & Kriteria \\
\hline pemahaman & - & 0,000 & $<0,05$ & berbeda
\end{tabular}

Sumber: Hasil Penelitian (2021)

Berdasarkan tabel 1 dikatakan bahwa nilai sig.( 2-tailed ) sebesar 0,000 $<0,05$ maka dapat dikatakan bahwa terdapat perbedaan yang nyata antara pengetahuan yang ditunjukan mahasiswa sebelum dan sesudah pelatihan hazard and safety. Peningkatan kompetensi pada aspek tingkat pemahaman mahasiwa sebelum dan sesudah pelatihan disajikan pada gambar 1 dibawah ini: 


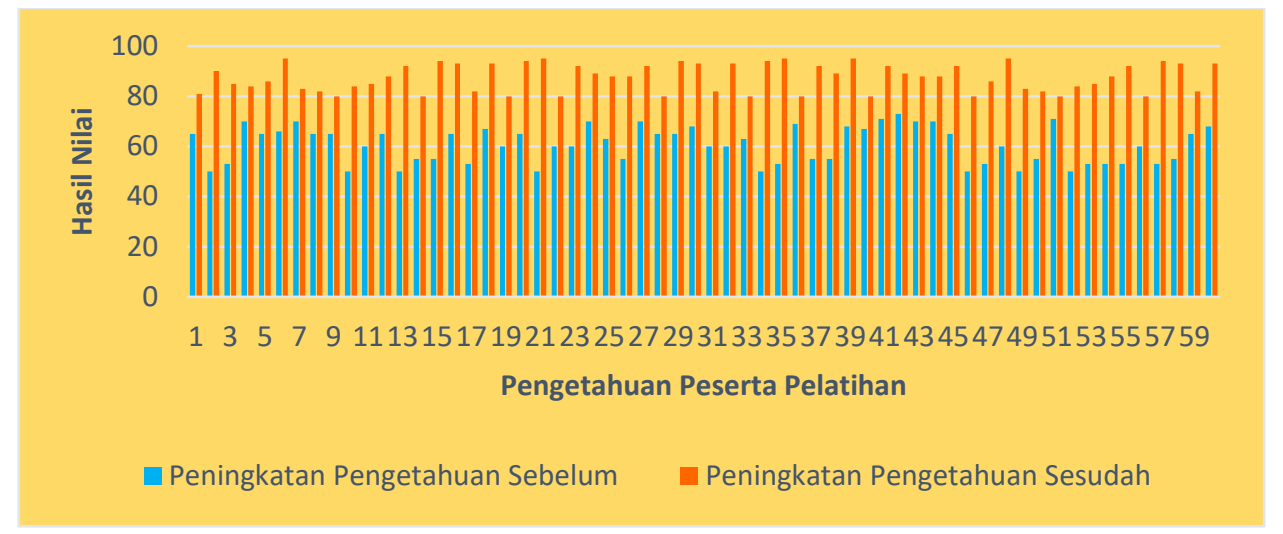

Gambar 1. Hasil Tingkat Pemahaman Mahasiswa Sebelum dan Sesudah Pelatihan Sumber: Hasil Penelitian (2021)

Berdasarkan data diatas dapat diambil kesimpulan bahwa mahasiswa memiliki tingkat pemahaman yang meingkat sebelum dan setelah pelatihan hazard and safety. Menurut Peng, et al., (2020), Pengetahuan yang baik, akan mendorong sikap positif. Hal ini didukung penelitian yang dilakukan di Uganda yang mempunyai pengetahuan baik maka memiliki sikap yang baik pula (Ssebuufu, et al., 2020). Sejalan dengan hasil penelitian Suprayitno et al (2020) Seseorang dengan pendidikan yang lebih tinggi apabila di berikan stimulus tentang pendidikan kesehatan maka akan bersikap terhadap stimulus yang telah diberikan, sehingga sikap sejalan dengan pengetahuan kesehatan yang dimiliki seseorang

Evaluasi sikap bertujuan untuk menilai sikap mahasiswa sebelum pelatihan dan setelah mengikuti pelatihan. Menurut Notoatmodjo (2012) tingkatan sikap terdiri dari: a) Receiving; b) Responding; c) Valuing dan d) bertanggung jawab. Tabel 2 menyajikan hasil penilaian tingkat signifikansi pelatihan hazard and safety pada aspek sikap mahasiswa sebelum dan sesudah pelatihan adalah sebagai berikut:

Tabel 2. Hasil Penilaian Aspek Sikap

\begin{tabular}{lllll}
\hline Aspek & Indikator & sig & A & Kriteria \\
\hline sikap & Receiving & 0,001 & $<0,05$ & Berbeda \\
& Responding & 0,001 & $<0,05$ & Berbeda \\
& Valuing & 0,001 & $<0,05$ & Berbeda \\
& Bertanggung Jawab & 0,004 & $<0,05$ & Berbeda \\
\hline
\end{tabular}

Sumber: Hasil penelitian (2021)

Penilaian tingkat keefektifan pelatihan hazard and safety menunjukkan hasil signifikansi yaitu (sig) < 0,05 maka hasil uji paired sample t test menunjukan bahwa pelatihan hazard and safety dapat meningkatkan sikap mahasiswa dalam melaksanakan unit produksi di era new normal sesuai protokol kesehatan. Sikap positif mahasiswa ditunjukan dengan minat dan ketertarikan terhadap pelatihan yang diberikan. Gambar 2 menyajikan Hasil peningkatan aspek sikap mahasiswa sebelum dan setelah pelatihan dapat dilihat pada gambar berikut ini: 


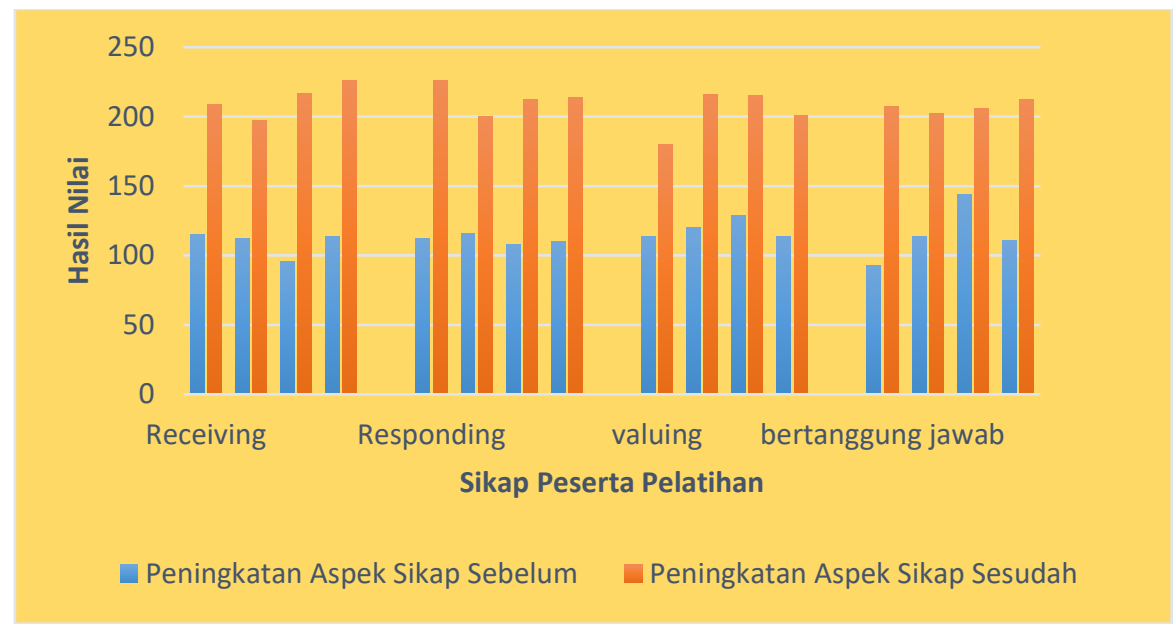

Gambar 2. Hasil Peningkatan Aspek Sikap Sebelum dan Sesudah Pelatihan Sumber: Hasil Penelitian (2021)

Berdasarkan hasil penelitian dan analisa yang dilakukan, bahwa pelatihan hazard and safety yang diselenggarakan dapat mempengaruhi sikap mahasiswa dalam melaksanakan unit produksi dengan tetap mematuhi protokol kesehatan. Hal ini dilihat dari sikap yang ditunjukkan mahasiswa setelah pelatihan serta intensi yang semakin meningkat setelah mengikuti program pelatihan ini. Melalui program pelatihan hazard and safety, peserta pelatihan mendapatkan pengetahuan yang belum pernah didapat, bahkan setelah mengikuti pelatihan tidak hanya menunjukan sikap dan intensi, melainkan juga sampai pada peningkatan ketrampilan baik dalam melaksanakan unit produksi maupun ketika perkuliahan praktek di bengkel kerja sesuai protokol kesehatan. Perlu adanya monitoring dan evaluasi agar pelaksanaan protokol kesehatan dalam melaksanakan unit produksi dapat konsisten diterapkan. Menurut Azwar (2013) tindakan itu dilakukan selama dalam pengawasan, sehingga perlu terus dilakukan pemantauan agar perubahan perilaku bersifat menetap. Perubahan perilaku individu menjadi optimal jika perubahan terjadi melalui proses kesadaran dalam diri individu, dimana perilaku yang baru dianggap bernilai positif bagi individu setelah diaplikasikan dengan tindakan individu dapat menjadi lebih baik.

\section{SIMPULAN DAN SARAN}

New normal menjadikan mahasiswa mengubah perilaku maupun aktivitas dalam mengelola unit produksi. Perubahan tersebut mengharuskan mahasiswa beradaptasi sehingga unit produksi dapat bertahan dan berkalanjutan. Strategi utama agar unit produksi tetap efektif sebagai tempat pelatihan kewirausahaan di era new normal adalah melalui pelatihan hazard and safety. Tujuan pelatihan ini adalah meningkatkan pengetahuan dan sikap mahasiswa dalam melaksanakan unit produksi di era new normal. Mahasiswa yang memiliki tingkat pemahaman tentang konsep hazard and safety menunjukan sikap positif dalam mengelola unit produksi sesuai protokol kesehatan. Hal ini menunjukan bahwa melalui program pelatihan hazard and safety, peserta pelatihan mendapatkan pengetahuan yang belum pernah mereka dapat, bahkan setelah mengikuti pelatihan tidak hanya menunjukan sikap dan intensi, melainkan juga sampai pada peningkatan ketrampilan baik dalam melaksanakan unit produksi maupun ketika perkuliahan praktek di bengkel kerja sesuai protokol kesehatan.

\section{DAFTAR PUSTAKA}

1. Azwar, S. (2013). Sikap Manusia: Teori dan Pengukurannya. In Sikap Manusia: Teori dan Pengukurannya. https://doi.org/10.1038/cddis.2011.1

2. Firman. (2020). Dampak Covid-19 Terhadap Perguruan Tinggi. Bioma Vol.02 No.1

3. Jamaluddin, D., Ratnasih, T., Gunawan, H., \& Paujiah, E. (2020). Pembelajaran daring masa pandemik Covid-19 pada calon guru: hambatan, solusi dan proyeksi.LP2M

4. Kuntarto, E. (2017). Keefektifan Model Pembelajaran Daring dalam Perkuliahan Bahasa Indonesia di Perguruan Tinggi. Indonesian Language Education and Literature,3(1), 99-110.10.24235/ileal.v3i1.1820

5. Mahfud, TuatuldanPardjono. 2012. Praksis Pembelajaran Kewirausahaan Pada Unit Produksi Jasa Boga. 
Jurnal Pendidikan Vokasi, Vol 2, Nomor 1, Februari 2012.

6. Moore, J. L., Dickson-Deane, C., \& Galyen, K. (2011). E-Learning, online learning, and distance learning environments: Are they the same? Internet and Higher Education. https://doi.org/10.1016/jiheduc.2010.10.001

7. Notoatmodjo, 2012, Promosi Kesehatan dan Ilmu Prilaku, Jakarta: PT Rineka Cipta

8. Peng, Y. et al., 2020. Knowledge, Attitude and Practice Associated with COVID-19 among. Research square.

9. Silvatika, Bayu Anggara. 2020. Technosociopreneur, New ModelUMKM di Era New Normal. Prosiding Seminar Stiami P-ISSN 2355-2883 Volume 7, No. 2, Oktober 2020.

10. Ssebuufu, R. et al., 2020. Awareness, knowledge, attitude and practice towards measures for prevention of the spread of COVID-19 in the Ugandans: A nationwide online cross-sectional Survey. medRxiv

11. Strielkowski, W. (2020). COVID-19 pandemic and the digital revolution in academia and higher education.Preprints,(April), 1-6. https://doi.org/10.20944/preprints202004.0290.v1

12. Suharto, S., Gurning, F. P., Pratama, M. Y., \& Suprayitno, E. (2020). Implementasi Kebijakan Penanggulangan HIV/AIDS di Puskesmas Teladan. Jurnal Riset Hesti Medan Akper Kesdam I/BB Medan, 4(2), 131-136.

13. Suprayitno, E., Purnomo, J. D. T., Sutikno, S., \& Indriyani, R. (2020). Health education in principle of community affected teenagaer's smooking attitude and habitual in the coastal area of madura island indonesia. International Journal of Psychosocial Rehabilitation, 24(10), 1492-1502. https://doi.org/10.37200/IJPR/V24I10/PR300173

14. Zhang, D., Zhao, J. L., Zhou, L., \& Nunamaker, J. F. (2004). Can e-learning replace classroom learning? Communications of the ACM.https://doi.org/10.1145/986213.986216 